Investigations

\title{
Recovered Gases and Bacteria from the Clostridium Genus as Ecological Condition Indicators of Bottom Sediments of the Eastern Donbass Small Rivers
}

\author{
Roman Gennad'yevich Trubnik, Yuriy Aleksandrovich Fedorov and Ludmila Anatol'yevna Nedoseka \\ Southern Federal University, 344006, 105/42 st. Bol'shaya Sadovaya, Rostov-on-Don, Russia
}

\author{
Article history \\ Received: 29-04-2017 \\ Revised: 06-07-2017 \\ Accepted: 24-07-2017 \\ Corresponding Author: \\ Roman Gennad'yevich Trubnik \\ Southern Federal University, \\ 344006, 105/42 st. Bol'shaya \\ Sadovaya, Rostov-on-Don, \\ Russia \\ E-mail : trubnikroman@outlook.com
}

\begin{abstract}
The results of determination of methane, total hydrogen sulfide and sulfite reducing clostridia in bottom sediments of small rivers and reservoirs of the Eastern Donbass are presented. The horizontal and vertical distribution of levels of reduced gases in bottom sediments is analyzed. The ecological condition of the bottom sediments was estimated by the clostridia titer and the methane index. The ranking of the ecological condition of bottom sediments according to the content of total hydrogen sulfide in them is performed. The relationship between $\mathrm{pH}$ and Eh values, methane and hydrogen sulfide concentrations and the number of sulfite reducing clostridia was studied, which allowed to discover new sides of the metabolic cycle of reduced gases in bottom sediments of freshwater ecosystems located in the zone of anthropogenic influence. The researches carried out allow to draw a conclusion about significant prolonged anthropogenic impact, mainly of domestic and industrial wastewater on water objects of the Eastern Donbass.
\end{abstract}

Keywords: Eastern Donbass, Clostridium, Total Hydrogen Sulfide, Methane, Bottom Sediments

\section{Introduction}

The investigations were carried out on small rivers of the Eastern Donbass Table 1, Fig. 1. This region is located in the South of the European territory of Russia in Rostov region and it is the main coal resource base of the Southern Federal District. The complex ecological situation in the small rivers of the Eastern Donbass is burdened by the negative consequences of the functioning of the coal industry, mainly due to the prolonged pollution of rivers by mine water runoffs containing increased concentrations of sulfate, chloride ions and sodium ions, iron compounds, heavy metals and low $\mathrm{pH}$ value. Aggressive mine waters are discharged into water bodies and streams that are already under the massive influence of domestic sewage containing a large number of biogenic components and bacteria of various degrees of pathogenicity (Fedorov et al., 1991; Fedorov, 1999; Labinskaya and Volina, 2008). A vivid example of such microorganisms is representatives of the Clostridium genus. Clostridia (Latin Clostridium) are gram-positive spore-forming anaerobic bacteria. According to Bergey's determinant
(Holt, 2000), this genus contains more than 100 species of saprophytic and pathogenic bacteria. The life activity of clostridia is carried out under anaerobic conditions and is accompanied by the production of toxins, enzymes and proteins that determine gas formation and necrosis in tissues, as well as a general toxic effect on the human body, animals and hydrobionts (Bylova et al., 2011; Shevchenko et al., 2013; Morozova and Fedorov, 2015). In the Russian Federation, quantitative accounting of sulfite-reducing clostridia is provided for soil, therapeutic mud, drinking water, sources of centralized domestic drinking water supply and open water bodies (EHCHiGOS, 1989; MI, 1999; EHCHiGOS, 2001). It is important to emphasize that oily-acid bacteria from the Clostridium genus ferment various carbohydrates, carry out the most important stage of anaerobic decomposition of organic matter in aquatic ecosystems and serve as the main precursors of sulfate reductors and methanogens (Dzyuban, 2005). According to the authors (Fedorov et al., 2014), bacteria from the Clostridium genus can take part in the production of methane and hydrogen sulfide in bottom sediments, but in situ this phenomenon has not been thoroughly studied. This, along with the solution of 
the applied problem- the complex use of the number of cells of sulfite-reducing clostridia and data on the content of methane and hydrogen sulfide for assessing the ecological condition of bottom sediments of small rivers and reservoirs of the Eastern Donbass and served as the basis for conducting original experimental studies.

We note that in the works (Fedorov et al., 2015; 2016a), for the first time an attempt was made to consider the relationship between the physicochemical parameters and the content of reduced gases with sulfite-reducing clostridia on a limited material. In this study we present an extensive and in-depth study carried out by us under natural conditions, which allows us to obtain the most correct and reliable data.

\section{Materials and Methods}

Expeditionary surveys on small rivers and water bodies were conducted on the territory of the Eastern Donbass between October 8-9, 2014 and September 2-3, 2015 Fig. 1.

The sampling stations were located on the most characteristic water objects, subject to anthropogenic impact of mine and municipal wastewater. Station No. 1 and 8 have the same geographical coordinates. Within the station No. 1, samples were taken in 2014 and at station No. 8 in 2015. The same situation occurs with stations No. 2 and 9, respectively. We have studied water objects in the vicinity of the town of Shakhty (the Grushevka River, the Ayuta River, the Kadamovka River, the Artemovskoye Reservoir and the Atyutinskaya and Yuzhnaya Reservoir Sediments), Belaya Kalitva (the Kalitva River, the Kundruchya River and several streams) and Kamensk-Shakhtinsky (the river Glubokaya). As a result of two expeditions, 52 samples of bottom sediments were sampled at 13 stations, which allow us to present the results of the study, relying on a significant array of data. Samples are selected at a distance of 1 to $2 \mathrm{~m}$ from the shore, a depth of 1 meter. Within each station, layers of bottom sediments were tested in the interval 0-2, 2-5, $5-10 \mathrm{~cm}$. At stations where the density of bottom sediments allowed to take deeper layers (all, except for stations No. 2, 11 and 12), samples were selected in the depth range of 10-15, 15-20 and 20-25 cm. In the layers indicated above, the values of $\mathrm{Eh}, \mathrm{pH}$, concentrations of $\Sigma \mathrm{H}_{2} \mathrm{~S}$ and $\mathrm{CH}_{4}$ and CFU/g of sulfitereducing clostridia were determined. Sampling of bottom sediments was carried out using a specially designed plastic tube with sharp edges and a piston to extrude the core (Gar'kusha et al., 2010). The values of $\mathrm{Eh}$ and $\mathrm{pH}$ in the bottom sediments were measured using electrodes of the portable $\mathrm{pH}$ meter of the ionomer-"Ecotest 2000".

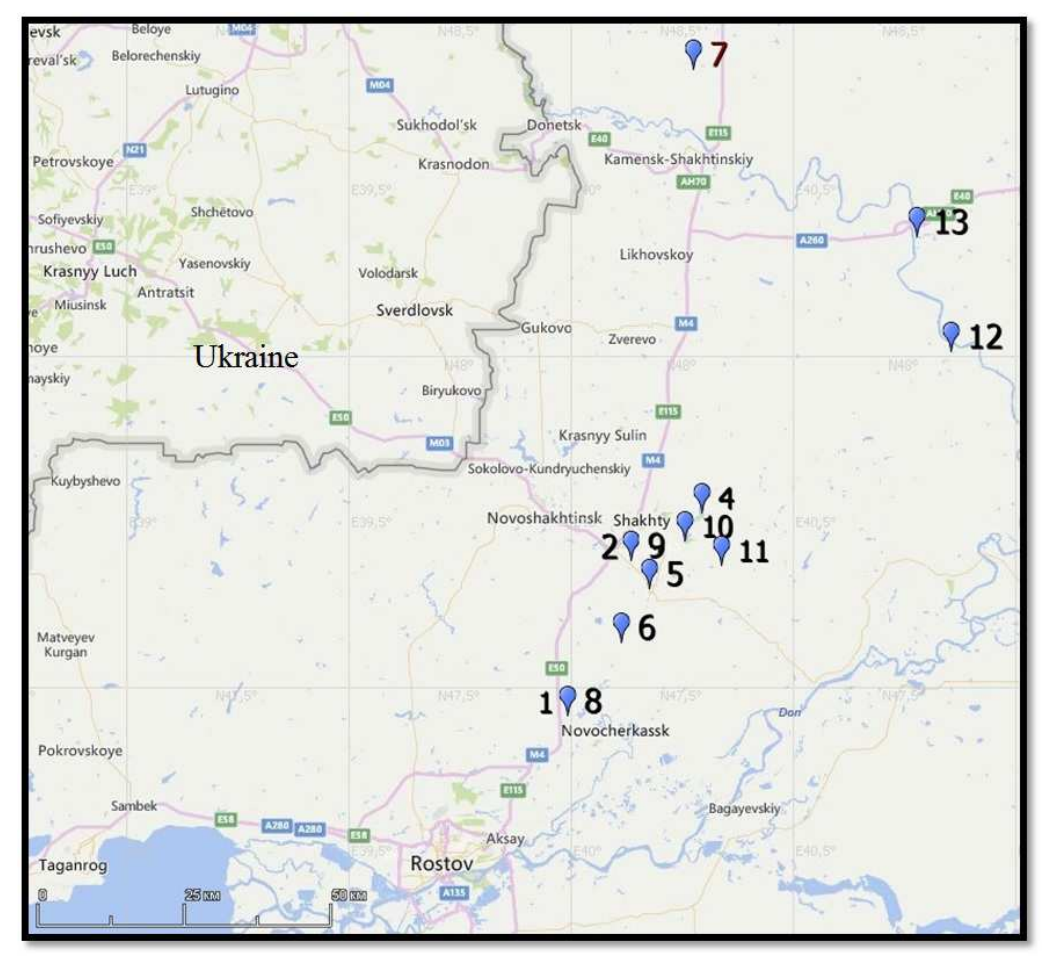

Fig. 1. Map of the location of sampling stations 
Determination of methane and hydrogen sulfide content in bottom sediments was carried out by the staff of the Hydrochemistry Institute (Rostov-on-Don) according to generally accepted methods: Methanevapor-phase gas chromatography method (Fedorov et al., 2005; Gar'kusha et al., 2010), total hydrogen sulfidephotometric method with dimethyl para phenylenediamine (Roshydromet, 2011). Data on the content of methane and hydrogen sulfide in the bottom sediments are given in $\mu \mathrm{g} / \mathrm{g}$ wet mass and $\mathrm{mg} / \mathrm{g}$ wet mass ( $\mu \mathrm{g} / \mathrm{g}$ and $\mathrm{mg} / \mathrm{g}$ w. m.), respectively. The quantitative determination vegetative cells of sulfite-reducing clostridia was carried out according to the generally accepted methodology (Labinskaya and Volina, 2008), which does not involve heating the inoculum (in a water bath at 75 $( \pm 5)^{\circ} \mathrm{C}$ for $15 \mathrm{~min}$ ), which promotes spore germination. Data on the number of sulfite-reducing clostridia in each layer of bottom sediments were obtained in $\mathrm{CFU} / \mathrm{g}$ and then transferred to the clostridia titer for the subsequent assessment of the bottom sediments ecological condition. The clostridia titer is determined from the maximum dilution in which clostridia are found, i.e., the clostridia titer is the lowest amount of bottom sediment, expressed in grams, which contains at least one viable cell of sulfite-reducing clostridia. Statistical, graphical processing of results and analyzes of studies was carried out using the MS Excel software package.

\section{Results and Discussion}

An important role in the distribution of reduced gases is played by the litho logical composition of the bottom sediments. It turned out that in spite of the different composition and hydrological regime of the studied water bodies, including rivers, streams and sedimentation basins, the bottom sediments of reservoirs and watercourses are generally homogeneous by their litho logical composition. Bottom sediments are clay silt from dark gray to black. The surface layer $(0-5 \mathrm{~cm})$, as a rule, it is abundantly moistened, while the density of silt increases with depth. For bottom sediments of stations No. $8,10,12,13$, small inclusions of sand material are characteristic, which are most often located in deeper layers, below about $10 \mathrm{~cm}$. It was previously established that the levels of reduced gases, especially methane, in sandy sediments are much lower, than in the silt (Fedorov et al., 2014). Analysis of the data showed Table 1 that in the homogeneous plastic fine-grained black muds (stations No. 2, 4, 6, 7) increased concentrations of methane and hydrogen sulfide or one of the gases were recorded. Almost all tested bottom sediments had the smell of hydrogen sulfide, which, along with the presence of semi-decomposed remains of aquatic vegetation, indicates the dominance of anaerobic conditions. It should be noted that the sediments of the stream near Sinegorsky (station No. 12) are fundamentally different from all those investigated by us. Here the layer $0-2 \mathrm{~cm}$ is represented by a liquid from rusty to orange sediment, bottom sediments in the depth interval $2-10 \mathrm{~cm}$ are composed of dark gray and gray muds with black silty inclusions. The lower layers of sediments contain up to $50 \%$ of gravel, sand and pebble material. The unusual color of the sediment is presumably due to the relatively recent erosion of a creek of rocks containing large amounts of iron as a result of the construction of infrastructure facilities, the development of quarries or the breaking of the surface of waste pits. Water within the sampling site also contained suspended particles of rusty color. Studies have shown that the concentration of gross iron in water is $3.25 \mathrm{mg}$ $\mathrm{I}^{-1}$, an average of 10-15 times higher than at other stations (Fedorov et al., 2016b). The bottom sediments of station No. 5 (the settler of the Ayutinskaya mine) are homogeneous in structure black silt, which is composed of finely dispersed carbonaceous particles without the slightest smell of $\mathrm{H}_{2} \mathrm{~S}$ potential. Note that the data on the redox potential Table 1, the content of methane and hydrogen sulfide here are strikingly different from other stations. The positive Eh value, the absence of traces of sulfide sulfur and the meager methane content are the result of special physical and chemical conditions formed within the sedimentation tank.

In addition to the lithological composition, the distribution of the reduced gases in the bottom sediments may have effect on the hydrogen ion index and redox potential values. In the bottom sediments of the studied water bodies Table 1, the $\mathrm{pH}$ value varies from neutral to slightly alkaline, which indicates similar conditions of the acid-alkaline environment. Redox potential mainly varies from -315 to $-11.7 \mathrm{mV}$, therefore bottom sediments are characterized by reducing conditions. The exception is the sedimentation pit of the Ayutinskaya mine (station No. 5), where the positive values of Eh are fixed and the oxidizing conditions prevail. It is established that the vertical distribution of $\mathrm{pH}$ along bottom sediments is not characterized any distinct regularity. The results of the earlier study showed that a direct inhibitory or activating effect of acid-alkaline conditions in the range $\mathrm{pH}=6-8$ do not affect by the level of concentrations of reduced gases (Gar'kusha et al., 2010). The oxidation-reduction potential of bottom sediments plays an important role in the distribution of $\mathrm{CH}_{4}$ and $\Sigma \mathrm{H}_{2} \mathrm{~S}$, as it affects the distribution and activity of methanogens and sulfate reductors that form these reduced gases. This is confirmed by the presence of 
close correlation dependences between the values of Eh and the concentrations of $\mathrm{CH}_{4}$ and $\mathrm{\Sigma H}_{2} \mathrm{~S}$, established for the example of various water bodies (Gar'kusha et al., 2010; Fedorov et al., 2016a) and in our research of the water objects of the Eastern Donbass.

At present, methane is one of the most promising indicators of the ecological condition of water bodies. Its highest concentrations in the bottom sediments of urbanized areas are confined to areas of powerful anthropogenic pressure and are clearly associated with the supply of organic substances by household and industrial wastewater (Fedorov et al., 2005; Gar'kusha et al., 2013). Thus, trace concentrations of methane are present at station No. 5 (up to $0.27 \mu \mathrm{g} \mathrm{g}^{-1}$ w. m.) and elevated methane concentrations have been detected within stations 4 and 7: From 9.3 to 21.3 and from 9.4 up to $26.8 \mu \mathrm{g} \mathrm{g}^{-1}$. respectively, which indicates the contamination of water bodies with organic substances and, thus, favorable conditions are created for the life of methanogen bacteria sometimes and throughout the depth of the core up to a mark of substances, which are presumed to enter bottom sediments with household and industrial wastewater. This leads to the development of an unfavorable ecological situation in water bodies and confirms the idea that methane serves as a Glubokaya River, north of the town of Kamensk-Shakhtinsky). Here, the bottom sediments in the methane content are estimated as highly contaminated. Thus, the results of the study show increased concentrations of methane in the bottom sediments, which signals contamination with organic sensitive indicator of the course of in-water processes and the ecological condition of aquatic ecosystems. Let us also pay attention to the vertical distribution of levels of methane and hydrogen sulfide in the bottom sediments Fig. 2. We note the tendency for increasing concentrations of methane with depth common to all sections, while the content of total hydrogen sulfide has a tendency to lower gas levels towards deeper layers of bottom sediments.

As well as methane, sulfur compounds can serve as an indicator of the ecological condition of water bodies. The main indicator is hydrogen sulfide. Its elevated levels in water and/or in bottom sediments indicate the contamination of the reservoir with organic substances of different origin and recovery conditions. In addition, changes in the oxygen regime of water bodies in the presence of sulfur compounds also lead to an increase in the abundance of anaerobic microflora, including sulfatereducing bacteria, as well as bacteria from the genus Clostridium. The results of the study showed that the minimum content of the mass fraction of total hydrogen sulfide in the bottom sediments of the Ayutinskaya Mine (station No. 5) is less than $0.005 \mathrm{mg} \mathrm{g}^{-1}$ w. m., while in the reservoir on the river Grushevka (station No. 10) reaches $4.02 \mathrm{mg} \mathrm{g}^{-1}$ of $\mathrm{w}$. $\mathrm{m}$. In the layer of bottom sediments $5-10 \mathrm{~cm}$.

Elevated levels of total hydrogen sulfide in bottom sediments are an indicator of the active development of regenerative processes occurring during bacterial decomposition of organic substances of autochthonous and allochthonous origin. It is no secret that the active development of such processes over time leads to serious environmental problems, such as overseas phenomena, deterioration of water quality, etc. Despite the fact that hydrogen sulfide, at certain levels of content, is toxic to living organisms (including humans), the maximum permissible concentrations of reduced gas for bottom sediments in the Russian Federation are not officially approved. Consequently, against the backdrop of the ever increasing anthropogenic press on the aquatic landscapes, there is a need to develop a methodologically sound, reliable and unified system for assessing the ecological condition of water bodies and streams, based on the levels of sulfur compounds in bottom sediments. The complexity of the issue lies in the choice of gas concentrations, which will serve as the basis for determining the ecological conditions of water bodies. Moreover, when developing evaluation criteria, it is necessary to take into account the effect on the content of total hydrogen sulfide in bottom sediments of the natural process of sulfate reduction, which occurs in water bodies under certain conditions. The evaluation criteria are based on data on the content of hydrogen sulfide compounds in the bottom landscapes of water bodies with different hydro chemical conditions and the degree of anthropogenic load. So, for example, the content of sulfides (total hydrogen sulfide) in indigenous, unaffected sediments of Lake Tambukan varies from 0.002 to $0.056 \mathrm{mg} \mathrm{g}^{-1}$ (Fedorov et al., 2014). It was shown in the work (Fedorov, 1999) for the Azov Sea that in aboriginal deposits the concentration of total hydrogen sulfide sharply decreases, reaching $0.02 \mathrm{mg} \mathrm{g}^{-1}$ w. m. The results of the Tsimlyansk reservoir study showed that the content of total hydrogen sulfide in the bedrock does not exceed $0.05 \mathrm{mg} \mathrm{g}^{-1} \mathrm{w}$. $\mathrm{m}$. In this connection, we considered it appropriate to take the content of hydrogen sulfide $<0.05 \mathrm{mg} \mathrm{g}^{-1}$ w. m. For background values and to classify such bottom sediments as "relatively pure". It should be added that the maximum permissible concentrations of sulfides, including free hydrogen sulfide, in the water of drinkingwater and domestic water use facilities are $0.003 \mathrm{mg} \mathrm{L}^{-1}$ (HSRF, 2003) and for chemicals in the soil-0.0004 mg $\mathrm{g}^{-1}$ (HSRF, 2006), which is several times lower than our background concentrations. 


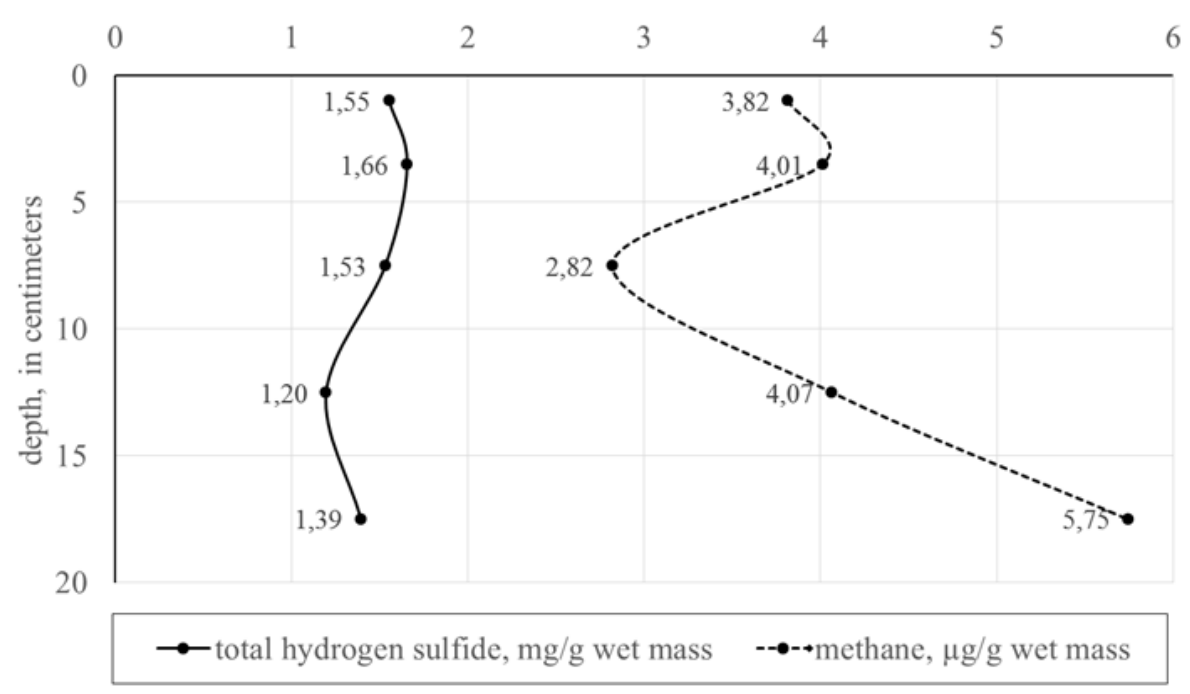

Fig. 2. Average distribution of methane and total hydrogen sulfide in the depth of bottom sediments (all stations)

According to studies (Fedorov, 1999), the average values of the content of total hydrogen sulfide in the bottom sediments of the Azov Sea in the $0-40 \mathrm{~cm}$ layer are $0.5 \mathrm{mg} \mathrm{g}^{-1}$ w. m. The Azov Sea belongs to biologically active water bodies, in the water and bottom sediments of which there are many organic substances and the processes of methane genesis and sulfate reduction are intensively taking place. As for small rivers, the cause of activation of sulfate reduction processes is a powerful anthropogenic impact. Therefore, the content of sulfides from 0.05 to $0.5 \mathrm{mg} \mathrm{g}^{-1} \mathrm{w}$. $\mathrm{m}$. characterizes the ecological condition of bottom sediments of small rivers as "slightly contaminated". Consequently, "contaminated" bottom sediments refer to sediments in which the content of total hydrogen sulfide varies from 0.5 to $1 \mathrm{mg} \mathrm{g}^{-1}$ w. $\mathrm{m}$. and bottom sediments with a total hydrogen sulfide content $>1 \mathrm{mg} \mathrm{g}^{-1}$ w. $\mathrm{m}$. are defined as "highly contaminated".

According to the above method, the ecological condition of the surface layer $(0-2 \mathrm{~cm})$ of bottom sediments was assessed. The results of the assessment showed that only sediment deposits of the Ayutinskaya Mine (station No. 5) are relatively pure. Bottom sediments of the stream, near the Sinegorsky settlement, are characterized as slightly contaminated (station No. 12). At all other stations, within which sampling was carried out, the bottom sediments are classified as highly contaminated.

Thus, we can assume that the water bodies and watercourses of the Eastern Donbass are under a powerful anthropogenic pressure. Quite high levels of hydrogen sulfide compounds in bottom sediments indicate the predominance of organic substances of allochthon origin in water bodies, which are actively involved in the process of generation of sulfur compounds as a substrate for bacteria-sulfate-reducers.

We note that the relationship of our indicators of the ecological condition of bottom sediments with each other and with Eh, $\mathrm{pH}$ value was before established in the work (Fedorov et al., 2016b). According to the results of the study, in the case of $\mathrm{pH}$, the correlation coefficient $R=0.13(p>0.05)$, which indicates a weak and insignificant relationship between the number of clostridia and the increase in the values of the hydrogen ion index. An inverse rectilinear relationship between the number of clostridia and the redox potential $(\mathrm{R}=$ $0.39)(\mathrm{p}<0.05)$ was recorded. For total hydrogen sulfide, the relationship with the number of clostridia is shown $(\mathrm{R}=0.36)(\mathrm{p} \leq 0.05)$. Also statistically significant, rather high values of the correlation coefficient $(R=0.52)(p<0.01)$ between the number of sulfite-reducing clostridia and the concentration of methane in the bottom sediments of the small rivers of the Eastern Donbass have been established (Fedorov et al., 2016a). All the correlation coefficient were received using the MS Excel software package.

Such correlation dependences demonstrate the connection between methane genesis and sulfate reduction processes with quantitative and qualitative composition of representatives of anaerobic micro flora of bottom sediments, which helps shed light on the role of sulfitereducing clostridia in the global sulfur and carbon cycle in aquatic landscapes under anthropogenic press.

Of course, for a comprehensive assessment of the ecological condition, it is necessary to involve data on microbiological characteristics of bottom sediments. In view of the above-described connection of reduced gases and bacteria from the Clostridium genus and also due to of their the high level of pathogen city, clostridia were selected as one of the indicators of the ecological condition of bottom sediments. Sulfite-reducing clostridia are known sanitary-indicative microorganisms. The detection of spores of sulfite-reducing clostridia indicates a long-standing fecal contamination (MI, 1999), while the number of vegetative cells is an 
indicator of relatively fresh fecal contamination. In addition, sulfite-reducing clostridia indirectly serve as an indicator of pollution by organic matter of bottom sediments because organic substances are a nutrient substrate for bacteria from the Clostridium genus, therefore, the higher the numbers of microorganisms, the more organic substances are available in accessible form in the bottom sediments. Also, it should be borne in mind that sulfite-reducing clostridia under favorable conditions can be present in the environment; therefore the criterion for assessing the ecological condition of bottom sediments is the number of microorganisms expressed in the titer of clostridia (EHCHiGOS, 1989).

\section{Discussion}

Analysis of the data obtained showed that bursts of the sulfite-reducing clostridia abundance were recorded primarily in the surface layer $(0-5 \mathrm{~cm})$ of the bottom sediments of the Glubokaya, Grushevka, Kadamovka, Artyomovsky, Grushevsky and Stream (st No.12) reservoirs Table 1. This is quite natural, since the surface layer of bottom sediments is subject to more "fresh" pollution and biochemically the most active, since it is located at the interface with the water column. The sedimentation pits of the Uzhnaya and Ayutinskaya mines show a peak in the number of microorganisms in the bottom sediment layer of 5-10 $\mathrm{cm}$, which means some improvement in the ecological situation at the water bodies, in comparison with the previous period. It is also significant that the number of clostridia in the layer of bottom sediments of 20-25 $\mathrm{cm}$ at station No.6 located at the mouth of the Ayuta River reaches $100,000 \mathrm{CFU} / \mathrm{g}$, while the average value in the $0-20 \mathrm{~cm}$ layer is about $4,000 \mathrm{CFU} / \mathrm{g}$, i.e., 25 times less. The results of the study are reflected in the assessment of the ecological condition of the bottom sediments of the water bodies of the Eastern Donbass from the sanitary-microbiological point of view Table 2. Thus, bottom sediments of 5 out of 12 stations by clostridia titer are classified as highly contaminated; the remaining 7 stations are contaminated. To highly contaminated we refer such water bodies as the river Glubokaya (st No.7), a sump of mine Uzhnaya (st No. 9), a water basin on the river Grushevka (st No. 10), the river Kadamivka (st No. 11) and the stream in Sinegorskiy (st No.12). Thus, the results of the studyallows us to conclude that over the years, domestic and industrial wastewater have a negative impact on the water arteries of the region.

Let us pay attention to the fact that the results of bottom sediments are representative and well reproducible. This can be verified by comparing the data for stations No. 1 and 8, 2 and 9, respectively. In the first case, a year later, the number of clostridia is reduced by one order, the level of methane in the surface layer of bottom sediments has decreased from 7.6 to $3.75 \mu \mathrm{g} \mathrm{g}^{-1}$ w. m., while the content of total hydrogen sulfide has increased from 0,72 to $1.2 \mathrm{mg} \mathrm{g}^{-1} \mathrm{w}$. m., which led to a slight deterioration in the ecological condition of bottom sediments in terms of total hydrogen sulfide content. In the second case, the positive dynamics of the ecological condition of bottom sediments was recorded: The content of total hydrogen sulfide and methane decreased somewhat, as a result, the category of the ecological condition changed from methane content from slightly contaminated to conditionally pure.

Also, one cannot but note the good convergence of the results of assessing the ecological condition of bottom sediments in all three indicators: The bottom sediments of station No. 5 (the sediment pit of the mine Uzhnaya) are characterized as relatively pure, the bottom sediments of station No. 1 (the mouth of the Grushevka River) are contaminated and the bottom sediments of station No. 4 (Artemovsky Reservoir) and No. 7 (the Glubokaya River) are estimated as highly contaminated Table 2 of all the sampling stations, only station No. 12 (stream) is knocked out of the logic of the results, here the bottom sediments of the clostridia titer are highly contaminated, the methane content is conditionally pure and the sulfide content is slightly contaminated. Most likely, this is related to the hydrological features of the stream, namely, with a fairly high flow velocity, a shallow depth of the water column and a specific litho logical composition of the bottom sediments. These factors can both interfere with the processes of methane genesis and sulfate reduction and also determine the intensive oxidation of the reduced gases formed in the bottom sediments. At six sampling stations, at first glance, our indicators characterize the bottom sediments "discordantly".

At the same time, there is a certain regularity associated with the levels of methane and sulfide content, which is well demonstrated by the categories of the ecological condition of bottom sediments. At stations No. 2, 11, 13, the characteristics of bottom sediments are as follows: The clostridia titer is contaminated, the methane content is slightly contaminated and the sulfide content is highly contaminated. A similar picture is also formed in the rest of stations No. 6, 9 and 10 . Here, the bottom sediments of the clostridia titer are contaminated, the methane content is relatively pure, the sulfide content is highly contaminated, i.e., the estimation of sulfide content at the designated 6 stations is significantly worse than in methane. It should be taken into account that the methane content is an indirect indicator of the ecological condition of bottom sediments, reflecting mainly the nature and speed of in-water processes, such as sedimentation, early diagenesis of precipitation, etc. In this case, the clostridia titer and levels of sulfide sulfur in the bottom sediments provide information on the degree of potential danger of a water body for living organisms. 
Roman Gennad'yevich Trubnik et al. / OnLine Journal of Biological Sciences 2017, 17 (3): 201.210 DOI: 10.3844/ojbsci.2017.201.210

Table. 1. Results of the study of bottom sediments of small rivers and reservoirs of the Eastern Donbass

\begin{tabular}{|c|c|c|c|c|c|c|}
\hline \multirow[b]{2}{*}{ Station №, location } & \multicolumn{6}{|c|}{ Bottom sediments } \\
\hline & Layer, cm & Eh, мB & $\mathrm{pH}$ & $\begin{array}{l}\text { SRC, thousand } \\
\text { CFU/g }\end{array}$ & $\begin{array}{l}\text { Methane, } \\
\mu \mathrm{g} / \mathrm{g} \text { w. m. }\end{array}$ & $\begin{array}{l}\text { Total hydrogen } \\
\text { sulfide, } \mathrm{mg} / \mathrm{g} \mathrm{w} . \mathrm{m} \text {. }\end{array}$ \\
\hline \multicolumn{7}{|l|}{ (1) $47^{\circ} 27^{\prime} 18,5 \mathrm{~N}$} \\
\hline \multirow[t]{5}{*}{$39^{\circ} 59^{\prime} 37,6 \mathrm{E}$} & $0-2$ & $-11,7$ & 7,67 & 10 & 7,60 & 0,72 \\
\hline & $2-5$ & $-93,5$ & 7.66 & 100 & 4,67 & 0,80 \\
\hline & $5-10$ & $-120,0$ & 7,81 & 100 & 2,12 & 1,49 \\
\hline & $10-15$ & $-123,0$ & 7,84 & 10 & 1,50 & 1,73 \\
\hline & $15-20$ & $-141,6$ & 7,72 & 0,5 & 1,11 & 2,16 \\
\hline \multicolumn{7}{|l|}{ (2) $47^{\circ} 41^{\prime} 25,4 \mathrm{~N}$} \\
\hline \multirow[t]{3}{*}{$40^{\circ} 08^{\prime} 05,3 \mathrm{E}$} & $0-2$ & $-116,0$ & 7,27 & 2,5 & 0,44 & 2,03 \\
\hline & $2-5$ & $-2-288,0$ & 7,37 & 2,9 & 0,25 & 2,89 \\
\hline & $5-10$ & $-3-315,0$ & 7,38 & 14 & 0,50 & 2,62 \\
\hline \multicolumn{7}{|l|}{ (4) $47^{\circ} 45^{\prime} 45,9 \mathrm{~N}$} \\
\hline \multirow[t]{5}{*}{$40^{\circ} 17^{\prime} 41,2 \mathrm{E}$} & $0-2$ & $-50,0$ & 7,45 & 90 & 9,33 & 1,08 \\
\hline & $2-5$ & $-113,0$ & 7,55 & 1 & 12,1 & 0,77 \\
\hline & $5-10$ & $-50,0$ & 7,59 & 9 & 14,8 & 0,49 \\
\hline & $10-15$ & $-135,0$ & 7,80 & 4 & 21,2 & 0,52 \\
\hline & $15-20$ & $-170,0$ & 7,58 & 1 & 16,4 & 0,21 \\
\hline \multicolumn{7}{|l|}{ (5) $47^{\circ} 38^{\prime} 53,9 \mathrm{~N}$} \\
\hline \multirow[t]{6}{*}{$40^{\circ} 10^{\prime} 36,8 \mathrm{E}$} & $0-2$ & $+103,0$ & 7,65 & 0,2 & 0,10 & $<0,005$ \\
\hline & $2-5$ & $+201,0$ & 7,68 & 1 & 0,16 & $<0,005$ \\
\hline & $5-10$ & $+204,0$ & 7,32 & 8,5 & 0,15 & $<0,005$ \\
\hline & $10-15$ & $+186,0$ & 7,60 & 1,3 & 0,15 & $<0,005$ \\
\hline & $15-20$ & $+162,0$ & 7,37 & 1 & 0,22 & $<0,005$ \\
\hline \multirow{2}{*}{\multicolumn{7}{|c|}{ (6) $47^{\circ} 34^{\prime} 00 \mathrm{~N}$}} \\
\hline & & & & & & \\
\hline \multirow[t]{6}{*}{$40^{\circ} 06^{\prime} 49,9 \mathrm{E}$} & $0-2$ & $-125,0$ & 7,66 & 2 & 0,04 & 2,30 \\
\hline & $2-5$ & $-245,0$ & 7,52 & 4,2 & 0,40 & 3,08 \\
\hline & $5-10$ & $-251,0$ & 7,51 & 5,5 & 0,47 & 2,72 \\
\hline & $10-15$ & $-286,0$ & 7,35 & 6 & 0,51 & 2,57 \\
\hline & $15-20$ & $-235,0$ & 7,50 & 2,4 & 0,81 & 2,70 \\
\hline \multirow{2}{*}{\multicolumn{7}{|c|}{ (7) $48^{\circ} 25^{\prime} 42,4 \mathrm{~N}$}} \\
\hline & & & & & & \\
\hline $40^{\circ} 16^{\prime} 35,4 \mathrm{E}$ & $0-2$ & $-210,0$ & 7,71 & 9000 & 21,8 & 2,18 \\
\hline & $2-5$ & $-225,5$ & 7,60 & 450 & 26,8 & 2,21 \\
\hline & $5-10$ & $-161,0$ & 7,60 & 650 & 12,9 & 2,13 \\
\hline & $10-15$ & $-171,0$ & 7,55 & 450 & 9,36 & 1,84 \\
\hline & $15-20$ & $-170,0$ & 7,59 & 300 & 10,2 & 1,89 \\
\hline 8) $47^{\circ} 27^{\prime} 18,5 \mathrm{~N}$ & & & & & & \\
\hline $39^{\circ} 59^{\prime} 37,6 \mathrm{E}$ & $0-2$ & $-135,0$ & 7,47 & 5 & 3,75 & 1,20 \\
\hline & $2-5$ & $-111,0$ & 7,65 & 10 & 0,92 & 1,95 \\
\hline & $5-10$ & $-102,0$ & 7,50 & 2 & 1,32 & 0,47 \\
\hline & $10-15$ & $-140,0$ & 7,49 & 0,5 & 2,41 & 1,06 \\
\hline (9) $47^{\circ} 41 ’ 25,4 \mathrm{~N}$ & & & & & & \\
\hline $40^{\circ} 08^{\prime} 05,3 \mathrm{E}$ & $0-2$ & $-114,0$ & 8,17 & 8 & 0,17 & 1,86 \\
\hline & $2-5$ & $-155,0$ & 7,77 & 1 & 0,51 & 0,95 \\
\hline & $5-10$ & $-229,0$ & 7,41 & 30 & 0,39 & 0,57 \\
\hline & $10-15$ & $-221,0$ & 7,80 & 10 & 0,49 & 1,35 \\
\hline (10) $47^{\circ} 43^{\prime} 11 \mathrm{~N}$ & & & & & & \\
\hline $40^{\circ} 15^{\prime} 21,8 \mathrm{E}$ & $0-2$ & $-230,0$ & 7,79 & 10 & 0,16 & 3,88 \\
\hline & $2-5$ & $-174,6$ & 7,72 & 80 & 0,22 & 3,60 \\
\hline & $5-10$ & $-155,0$ & 7,36 & 0,6 & 0,19 & 4,02 \\
\hline & $10-15$ & $-137,5$ & 7,01 & - & 0,18 & 0,74 \\
\hline (11) $47^{\circ} 40^{\prime} 56,9 \mathrm{~N}$ & & & & & & \\
\hline $40^{\circ} 20^{\prime} 22,9 \mathrm{E}$ & $0-2$ & -154.0 & 7,20 & 4 & 0,51 & 1,54 \\
\hline & $2-5$ & $-105,8$ & 6,79 & 1000 & 0,83 & 1,27 \\
\hline & $5-10$ & $-135,0$ & 7,65 & 1000 & 0,45 & 1,53 \\
\hline (12) $48^{\circ} 00^{\prime} 21,6 \mathrm{~N}$ & & & & & & \\
\hline $40^{\circ} 51^{\prime} 15,5 \mathrm{E}$ & $0-2$ & $-96,5$ & 7,42 & 1000 & 0,06 & 0,05 \\
\hline & $2-5$ & $-116,5$ & 6,88 & 5 & 0,17 & 0,03 \\
\hline & $5-10$ & $-64,5$ & 7,11 & - & 0,06 & 0,01 \\
\hline (13) $47^{\circ} 10^{\prime} 43,6 \mathrm{~N}$ & & & & & & \\
\hline $40^{\circ} 46^{\prime} 45,0 \mathrm{E}$ & $0-2$ & $-152,3$ & 7,58 & 9 & 1,82 & 1,79 \\
\hline & $2-5$ & $-168,4$ & 7,75 & 3 & 1,13 & 2,31 \\
\hline & $5-10$ & $-187,6$ & 7,66 & 9 & 0,47 & 2,28 \\
\hline & $10-15$ & $-163,8$ & 7,64 & - & 0,80 & 0,95 \\
\hline
\end{tabular}


Table 2. Characteristics of the upper layer $(0-2 \mathrm{~cm})$ of bottom sediments according to clostridia titer, methane and total hydrogen sulfide content

\begin{tabular}{|c|c|c|c|c|c|c|}
\hline Sampling Location & Titre & $\begin{array}{l}\text { Ecological situation } \\
\text { of the clostridia titre in } \\
\text { the bottom sediments }\end{array}$ & $\begin{array}{l}\text { Methane, } \\
\mu \mathrm{g} / \mathrm{g} \\
\text { w. m. }\end{array}$ & $\begin{array}{l}\text { Ecological situation of } \\
\text { the methane content in } \\
\text { the bottom sediments }\end{array}$ & $\begin{array}{l}\text { Total hydrogen } \\
\text { sulfide } \mathrm{mg} / \mathrm{g} \\
\text { w. } \mathrm{m} \text {. }\end{array}$ & $\begin{array}{l}\text { Ecological situation of } \\
\text { the hydrogen sulfide } \\
\text { the bottom sediments }\end{array}$ \\
\hline \multicolumn{7}{|l|}{ 1) Mouth of the river } \\
\hline \multicolumn{7}{|l|}{ Grushevka, stl. Vesely } \\
\hline $\mathrm{N} 47^{\circ} 27^{\prime} 18,5^{\prime \prime}$ & 0,0001 & Contaminated & 7,6 & Contaminated & 0,72 & Contaminated \\
\hline \multicolumn{7}{|l|}{ E 3959'37,6” (2014) } \\
\hline \multicolumn{7}{|l|}{ 2) Sump of the mine Uzhnaya } \\
\hline N $47^{\circ} 41^{\prime} 25,4^{\prime \prime}$ & 0,001 & Contaminated & 0,5 & Slightly contaminated & 2,03 & Heavily contaminated \\
\hline \multicolumn{7}{|l|}{ E 4008'05,3” (2014) } \\
\hline \multicolumn{7}{|l|}{ 4) Artyomovsky reservoir, Shakhty } \\
\hline${ }^{\prime} 45^{\prime} 45,9$ ' & 0,00001 & Heavily contaminated & 9,33 & Heavily contaminated & 1,08 & Heavily contaminated \\
\hline \multicolumn{7}{|l|}{ E $40^{\circ} 17^{\prime} 41,2 ”(2014)$} \\
\hline \multicolumn{7}{|l|}{ 5) Sump of mine Auytinskaya } \\
\hline N $47^{\circ} 38^{\prime} 53,9^{\prime \prime}$ & 0,01 & Pure & 0,10 & Relatively pure & $<0,005$ & Relatively pure \\
\hline \multicolumn{7}{|l|}{ E 40¹0’36,8” (2014) } \\
\hline & 6) Mouth of the river Auyta, & Contaminated & 0,04 & Relatively pure & 2,3 & Heavily contaminated \\
\hline \multicolumn{7}{|l|}{ E 4006'49,9”' (2014) } \\
\hline \multicolumn{7}{|l|}{$\begin{array}{l}\text { 7) River Glubokaya, to the north } \\
\text { of Kamensk-Shakhtinsky }\end{array}$} \\
\hline $\mathrm{N} 48^{\circ} 25^{\prime} 42,4^{\prime \prime}$ & 0,000001 & Heavily contaminated & 21,8 & Heavily contaminated & 2,18 & Heavily contaminated \\
\hline \multicolumn{7}{|l|}{ E $40^{\circ} 16^{\prime} 35,4^{\prime \prime}(2014)$} \\
\hline \multicolumn{7}{|l|}{ 8) Mouth of the river } \\
\hline \multicolumn{7}{|l|}{ Grushevka, stl. Vesely } \\
\hline $\mathrm{N} 47^{\circ} 27^{\prime} 18,5^{\prime \prime}$ & 0,001 & Contaminated & 3,75 & Contaminated & 1,2 & Heavily contaminated \\
\hline \multicolumn{7}{|l|}{ E 3959'37,6" (2015) } \\
\hline \multicolumn{7}{|l|}{ 9) Sump of the mine Uzhnaya } \\
\hline \multicolumn{7}{|l|}{ N $47^{\circ} 41^{\prime} 25,4^{\prime \prime}$} \\
\hline E 4008'05,3”'(2015) & 0,001 & Contaminated & 0,17 & Relatively pure & 1,86 & heavily contaminated \\
\hline \multicolumn{7}{|l|}{ 10) Reservoir of the river } \\
\hline \multicolumn{7}{|l|}{ Grushevka } \\
\hline 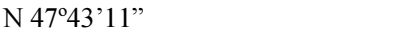 & 0,0001 & Contaminated & 0,16 & Relatively pure & 3,88 & Heavily contaminated \\
\hline \multicolumn{7}{|l|}{ E $40^{\circ} 15^{\prime} 21,8^{\prime \prime}(2015)$} \\
\hline \multicolumn{7}{|l|}{ 11) River Kadamovka } \\
\hline N $47^{\circ} 40^{\prime} 56,9^{\prime \prime}$ & 0,001 & Contaminated & 0,51 & Slightly contaminated & 1,54 & Heavily contaminated \\
\hline \multicolumn{7}{|l|}{ E 40²0’22,9”'(2015) } \\
\hline \multicolumn{7}{|l|}{ 12) Stream, stl. Sinegorsky } \\
\hline N 4800’21,6” & 0,000001 & Heavily contaminated & 0,06 & Relatively pure & 0,05 & Slightly contaminated \\
\hline \multicolumn{7}{|l|}{ E 4051'15,5” (2015) } \\
\hline \multicolumn{7}{|l|}{ 13) River Kalitva, stl. } \\
\hline Belaya Kalitva & & & & & & \\
\hline N 4810’43,6” & 0,001 & Contaminated & 1,82 & Slightly contaminated & 1,79 & Heavily contaminated \\
\hline E 4046’45,0” (2015) & & & & & & \\
\hline
\end{tabular}

So, sulfite-reducing clostridia are conditionally pathogenic microorganisms that are capable of causing such severe diseases as gas gangrene, tetanus, botulism and others. In turn, increased levels of total hydrogen sulfide in a water body can lead to mass death of hydrobionts, impairment of the organoleptic properties of water, etc.

The formation of methane and hydrogen sulfide occurs in bottom sediments as a result of complex metabolic transformations of organic matter and its decay products with the participation of an aerobicanaerobic pool of bacteria (Winfrey and Zeikus, 1977; Fedorov et al., 2005). These processes are especially active in the areas of bottom sediments that are subject to prolonged pollution with domestic water, which allowed using the "methane" and "sulfide" indicators to assess the degree of eutrophication and the ecological condition of the bottom sediments (Fedorov et al., 2005; Gar'kusha et al., 2013). As shown above, bacteria from the Clostridium genus are indicators of the pollution of aquatic ecosystems by municipal sewage and also play an important role in the metabolic cycle of production of reduced gases. In this connection, it seems reasonable to use the triad of these factors (the number of clostridia, the content of methane and total hydrogen sulfide) as indicators of the ecological condition of bottom sediments.

\section{Conclusion}

The results of the study demonstrated that the vegetative cells of sulfite-reducing clostridia are widely distributed within all investigated water objects, exceeding the normative indices by the titer of clostridia by two or more orders. The results of estimating bottom sediments by the content of methane and total hydrogen sulfide indicate the allochthonous intake of organic substances in water bodies and waterways of domestic and industrial wastewater. It 
should be added that only joint use of reduced gases and sulfite-reducing clostridia as indicators of the ecological condition of bottom sediments allows to obtain comprehensive information not only about the current condition of bottom sediments, but also trace the dynamics of anthropogenic impact on water bodies and watercourses over a long period of time. Thus, for the first time the in situ studies carried out make it possible to draw a conclusion about the unfavorable ecological condition of the water bodies of the Eastern Donbass. In this regard, a very urgent task is the implementation of systematic long-term observations on the basis of the investigated objects, in order to identify the main sources of pollutants and control the change in the ecological situation in the aquatic landscapes of the Eastern Donbass.

\section{Acknowledgement}

The research was carried out at the expense of a grant from the Russian Science Foundation (project 17-1701229 ) and the Southern Federal University (grant no. 5.5791.2017/6.7 (LC)). We acknowledge Marina Morozova for their skillful technical assistance and for her help with the analyses.

\section{Author's Contributions}

Roman Gennad'yevich Trubnik: Participated in all experiments, collected the field data and contributed to the writing of the manuscript.

Yuriy Aleksandrovich Fedorov: The head of the investigation, designed the research plan and organized the study, coordinated the data-analysis and contributed to the writing of the manuscript.

Ludmila Anatol'yevna Nedoseka: Contributed in drafting the manuscript and reviewing it critically for significant intellectual content.

\section{Ethics}

This article is original and contains unpublished material. The corresponding author confirms that all of other authors have read and approved the manuscript and no ethical issues involved.

\section{References}

Bylova, N.A., L.I. Kafarskaia and Z.A. Chernaya, 2011. Role of $\mathrm{Cl}$. Dificile in the development of systemic inflammation in often hospitalized patients with CHF. J. Serdechnaya Nedostatochnost', 12: 31-35.

Dzyuban, A.N., 2005. Oily acid bacteria belonging to the genus Clostridium in the bottom sediments of inland water bodies of different types. Mikrobiologiya (Microbiology), 74: 119-125.

EHCHiGOS, 1989. Methodological guidelines 1439/316-17: Methodological guidelines for the sanitary and microbiological analysis of therapeutic mud.
EHCHiGOS, 2001. Methodological guidelines 4.2.101801: Guidelines for the sanitary and microbiological analysis of drinking water.

Fedorov, Y.A., M.A. Morozova and R.G. Trubnik, 2015. Clostridium: Distribution, communication with hydrochemical indicators, methane and hydrogen sulphide in water objects of the Eastern Donbass. Proceedings of the Scientific Conference with International Participation "Modern Problems of Hydrochemistry and Surface Water Quality Monitoring Part 1, Sept. 8-10. Rostov-on-Don, Russia, pp: 270-274.

Fedorov Y.A., V.A. Grinenko, H.R. Krouse and A.M. Nikanorov, 1991. Use of hydrochemical and isotopic criteria for evaluation of the influence of technogenic sulphur on surface waters. Proceedings of the an International Symposium on Isotope Techniques in Water Resources Development, (WRD' 91), Vienna, Austria, pp: 477-494.

Fedorov, Y.A., 1999. Stable isotopes and evolution of the hydrosphere. Publishing house of the center "Istina" by MERF, Moscow.

Fedorov, Y.A., D.N. Garkusha and K.A. Afanasiev, 2014. Methane and hydrogen sulfide in therapeutic sulphide muds (on the example of Lake Bolshoy Tambukan) University news North-Caucasian region. Natural Sci., 3: 102-109.

Fedorov, Y.A., I.V. Dotsenko and L.Y. Dmitrik, 2016 a. Iron in surface and underground waters of the Azov Sea basin. University news. North-Caucasian region. Natural Sci., 3: 91-99.

Fedorov, Y.A., R.G. Trubnik and M.A. Morozova, 2016b. On the relationship of physicochemical parameters and the content of reduced gases with sulfite-reducing clostridia in bottom sediments of small rivers University news North-Caucasian region. Natural Sci., 1: 95-100.

Fedorov, Y.A., N.S. Tambieva, D.N. Gar'kusha and V.O. Khoroshevskaya, 2005. Methane in Aquatic Ecosystems. 1st Edn., Rostov-on-Don/Moscow, pp: 329.

Gar'kusha, D.N., Y.A. Fedorov and M.I. Khromov, 2010. Methane in the water and bottom sediments of the mouth of the Severnaya Dvina River (White Sea). Oceanology, 50: 498-512.

Gar'kusha, D.N., Y.A. Fedorov and N.S. Tambieva, 2013. Methane as an indicator of the conditions of early diagenesis and ecological condition of aquatic ecosystems University news North-Caucasian region. Natural Sci., 6: 78-82.

Holt, J.G., 2000. Bergey's Manual of Determinative Bacteriology. 1st Edn., Lippincott Williams and Wilkins, Philadelphia, ISBN-10: 0683006037, pp: 787.

HSRF, 2003. GN 2.1.5.1315-03: The Maximum Permissible Concentrations (MPC) of chemicals in water in water bodies of domestic and drinking and cultural and domestic water use. Hygienic Standard Russian Federation. 
HSRF, 2006. GN 2.1.7.2041-06: The Maximum Permissible Concentration (MPC) of chemicals in the soil. Hygienic Standard Russian Federation.

Labinskaya, A.S. and E.G. Volina, 2008. Manual on Medical Microbiology. 1st Edn., General and Sanitary Microbiology, Moscow, pp: 1080.

MI, 1999. Methodological instructions for the sanitarymicrobiological study of soil, (approved by the Ministry of Health of the USSR on 04/08/1976 N 1446-76) (as amended on 07.02.1999). Methodological Instructions.

Morozova, M.A. and Y.A. Fedorov, 2015. Role of sulfite-reducing clostridia in pathology in fish. University news North-Caucasian region. Natural Sci., 1: 60-66.
Roshydromet, 2011. Working documents 52.24.5252011: Mass fraction of total hydrogen sulfide in bottom sediments. Method for performing measurements by photometric method with $\mathrm{N}, \mathrm{N}$-diMethyl-p-phenylenediamine., GU GHI.

Shevchenko, A.A., O.Y. Chernykh and L.V. Shevchenko 2013. Diagnosis of Clostridiosis of Animals. 1st Edn., Krasnodar, Kubgau, pp: 36.

Winfrey, M.R. and I.G. Zeikus, 1977. Effect of sulfate on carbon and electron flow during microbial methanogenesis in freshwater sediments. Applied Environ. Microbiol., 22: 275-281. 